\title{
Toxicity and Antifeedant Effects of Apricot Kernel Extract and Its Main Components against Cotton Leaf Worm, Spodoptera littoralis (Lepidoptera: Noctuidae) Larvae With Reference To Some Physiological Effects
}

\author{
Wael M. Khamis ${ }^{1}$; Sahar E. El-Desouky ${ }^{1}$ and Abir A. Gad ${ }^{2}$
}

\begin{abstract}
Toxicity and antifeedant effect of hexane apricot kernel extract (HEAK) and its gas chromatography-mass spectroscopy (GC-MS) identified fatty acid (FA) components palmitic acid (PA), Oleic acid (OL) and FA derivatives (Linoleic acid methyl ester (LAME)) were assessed against $2^{\text {nd }}$ and $4^{\text {th }}$ instar larvae of Spodoptera littoralis under laboratory conditions. Methoxyfenozide (Runner $24 \%$ SC $^{\circledR}$ ) was used as reference insecticide to (HEAK) and its components. The results were statistically analyzed by probit analysis to calculate $\left(\mathrm{LC}_{50}\right)$ of mortality and the concentrations caused $50 \%$ of antifeedant index $\left(\mathrm{AI}_{50}\right)$ after 24, 48 and $72 \mathrm{hrs}$ of exposure. The results of toxic and antifeedant effects showed the definite prevalence of HEAK versus its FA components against the two instar larvae of $S$. littoralis throughout $72 \mathrm{hrs}$ of exposure. However the toxic initiation of the extract and its components paced methoxyfenozide by the first $24 \mathrm{hrs}$ of exposure, methoxyfenozide still owned a superior toxicity and antifeedant response on the treated larvae. This work has been associated with some physiological tests including haemocytes count and corpora allata (CA) activity.
\end{abstract}

Key words: apricot kernel extract, Spodoptera littoralis, methoxyfenozide, haemocytes, corpora allata, fatty acids.

\section{INTRODUCTION}

Larvae of cotton leaf worm (CLW), Spodoptera littoralis (Lepidoptera: Noctuidae) is so far one of the major destructive agricultural lepidopterous pests within subtropical and tropical zones. The pest causes a variety of damage as a leaf feeder and sometimes as a cutworm on seedlings. It can attack various economically important crops throughout the year (EPPO, 1997).

Even thought, conventional insecticides have become an indispensable tool in controlling some pest economically, rapidly and effectively, the extensive use of insecticides can have adverse impacts on non-target organisms and general environmental contamination (Georgiou, 1987 and Ditrich, 1962). According to Nas (2004) recent orientations towards botanical pesticides application in crop protection programs is on the rise. Many researchers have been recourse to develop an alternative plant extracts as pesticides to be used against insect pests.

Natural plant products are comparatively less toxic, easily biodegradable and have made them to be the best alternate to the synthetic pesticides. Effective insecticidal properties were investigated in several plant species of various families (Koshiya and Ghelani, 1990). Apricot kernels, depending on the variety, contain the toxic cyanogenic glycoside amygdalin (Gomez et al., 1998). Amygdalin can be hydrolyzed to form glucose, benzaldehyde and hydrocyanic acid. Enzymatic release of cyanide occurs in the presence of $\beta$-glucoronidase, an enzyme found in the human intestine (Shragg et al., 1982). Previous studies had been carried out on the extraction methods and chemical profiles of apricot kernel. A typical extracted oil fraction makes out around $45 \%$ of the weight of the seed. The triglyceride fatty acids (FAs) are mostly Oleic (OL), linoleic (LA) and Palmitic acid (PA). (Gupta et al., 2012)

Recent experimental attempt had been achieved on the insecticidal activity of some FAs like those originated in hexane extract of apricot kernel (HEAK) and many other plant extracts. Insectistatic and insecticidal activities of LA were performed against Spodoptera littoralis larvae (Youssef et al., 2013) and Spodoptera frugiperda larvae (Ramos-López et al., 2012). However, there was rarity of publications on the toxicity and antifeedant responds of OL and PA on insects, some recent studies have been revealed on the insecticidal activity of OL against Anopheles stephensi and Culex quinquefasciatus (Diptera: Culicidae) (Rahuman et al., 2008; Kannathansan et al., 2008).

Methoxyfenozide have been chosen as a reference insecticide in this study as it is considered as the newest and most potent synthetic ecdysone agonist and it binds to ecdysteroid receptors, inducing a premature and lethal molt in many insects, primarily lepidopteron pests (Smagghe et al. 2003) also its sub lethal effects include delayed developmental rates (Adel and Sehnal, 2000, Biddinger et al. 2006). Therefore, suggesting of apricot

\footnotetext{
${ }^{1}$ Dept. of Cotton Pesticides Bioassay Research, Plant Protection Research Institute, Agriculture Research Center, Al Sabhia, Alexandria, Egypt.

${ }^{2}$ Dept. of Applied Entomology, Faculty of Agriculture (El-Shatby), Alexandria University, Alexandria, Egypt.

Received October 11, 2016, Accepted December 4, 2016
} 
kernel extract in this study was attributed to its main constituents that possess toxic effect.

The aim of this study is to determine the lethal effect and antifeedant activity of methoxyfenozide on larvae of $S$. littoralis as a reference to HEAK. This work has been associated with some physiological tests that might elucidate approaches of insecticidal activity of HEAK's main FA constituents.

\section{MATERIALS AND METHODS}

\section{Plant material and extraction:}

Samples were collected from mature apricot fruits (Prunus armeniaca). After the shell removal, the kernels were left for drying at room temperature for about 10 days. The dried kernels were grinded in blender. Kernel oil was extracted with n-hexane (under heat temperature $45 \pm 5^{\circ} \mathrm{C}, 12 \mathrm{hr}$.) in Soxhelt extractor. Hexane solvent was removed under reduced pressure by rotary evaporator. The crude extract was stored in a sealed glass bottle at $0{ }^{\circ} \mathrm{C}$.

\section{Gas chromatography-mass spectroscopy (GC-MS) analysis}

The chemical composition of HEAK was performed in Nuclear Research Center (NRC), Egyptian Atomic Energy Authority, Inshas, Cairo, Egypt by using Trace GC Ultra-ISQ mass spectrometer (Thermo-Scientific, Waltham, MA) with a direct capillary column TG-5MS (30 m_0.25 mm_0.25 mm film thickness). The column oven temperature was initially held at $60{ }^{\circ} \mathrm{C}$ hold 3 to 150 with $10^{\circ} \mathrm{C} \mathrm{min}^{-1}$ ramp and then increased to $260{ }^{\circ} \mathrm{C}$ withhold time $5 \mathrm{~min}$ with $5{ }^{\circ} \mathrm{C} \mathrm{min}^{-1}$ ramp and split mode. The injector and detector (MS transfer line) temperatures were kept at $250{ }^{\circ} \mathrm{C}$. Helium was used as a carrier gas at a constant flow rate of $1 \mathrm{ml} \mathrm{min}^{-1}$. Extract derivatization was done using BSTFA/TMCS (80:20, v: v) for $1 \mathrm{~h}$ at $70{ }^{\circ} \mathrm{C}$, after evaporation to dryness of dichloromethane/methanol mixture. The resulting solution was dried and then dissolved in hexane. The solvent delay was $2 \mathrm{~min}$ and diluted samples of $1 \mathrm{ml}$ were injected automatically using Auto sampler AS3000 (Thermo-Scientific, Waltham, MA) coupled with GC in the splitless mode. EI mass spectra were collected at $70 \mathrm{eV}$ ionization voltages over the range of $\mathrm{m} / \mathrm{z} 50-650$ in full scan mode. The ion source and quadruple temperatures were set at $200{ }^{\circ} \mathrm{C}$ and $150{ }^{\circ} \mathrm{C}$, respectively. The components were identified by comparison of their retention times (Rt) and mass spectra with those of WILEY 09 (Flavor \& Fragrance Natural \& Synthetic Compounds) and NIST 11 (National Institute of Standards and Technology, Gaithersburg, MD) Mass Spectral databases.

\section{Tested synthetic compounds:}

The following synthetic compounds represent the main FA components found in HEAK previously identified by GC-MS analysis.

1. Oleic acid (OL) 98\% and Palmitic acid (PA) were purchased from (Lobachemie Co.).

2. Linoleic acid methyl ester 99\% (LAME) was purchased from (Sigma Aldrich).

3. Methoxyfenozide (Runner 24\% $\mathrm{SC}^{\circledR}$ from Dow Agro Science co.) was used as a reference insecticide.

\section{Strain of cotton leaf worm $\boldsymbol{S}$. littoralis}

The S. littoralis strain was reared in Integrated Protection Laboratory; Plant Protection Research Institute; Agriculture Research Center according to (ElDefrawi et al., 1964).

\section{Toxicity tests:}

Leaf of Ricinus communis were dipped for twenty seconds in sub lethal concentrations for HEAK and the tested synthetic fatty acid compounds with the concentrations range of (100-10000 $\left.\mathrm{mg} \mathrm{L}^{-1}\right)$ and (0.01$5 \mathrm{mg} \mathrm{L}^{-1}$ ) for methoxyfenozide (Runner $24 \% \mathrm{SC}^{\circledR}$ ). The treated leaves were left to dry at room temperature. One or two treated leaves were placed in each cup $(7 \mathrm{~cm}$ dia x $9 \mathrm{~cm} \mathrm{~L}$ ) for starved ( $24 \mathrm{hr}$.) $2^{\text {nd }}$ and $4^{\text {th }}$ instar larvae of $S$. littoralis, respectively. The larvae were allowed to feed on the treated leaves for $48 \mathrm{hr}$. then the leaves were replaced by new untreated one at $72 \mathrm{hr}$. For each concentration, 4 replicates were maintained. Each replicate has five larvae. Larval mortality was recorded after 24, 48 and $72 \mathrm{hr}$. of exposure periods. Mortality percent was calculated using the Abbott formula (Abbott, 1925) and subjected to probit analysis according to (Finney, 1971) by LDP line.

\section{Antifeedant effect:}

Leaf discs $\left(3 \mathrm{~cm}\right.$ dia. $\left.=706.81 \mathrm{~mm}^{2}\right)$ were dipped for twenty seconds in sub lethal concentrations, not exceed the upper limit of $\mathrm{LC}_{50}$ values of the same previous tested treatments against $2^{\text {nd }}$ and $4^{\text {th }}$ instar larvae of $S$. littoralis. Likewise, the experiment was design and allowed to run as well as in toxicity assay. The uneaten area of each leaf disc was weighted. The percent antifeedant activity was calculated based on the formula of (Saleh et al., 1986). Then all the data undergo concentration-responds probit analysis by LDP line to calculate the concentration that cause $50 \%$ of antifeedant index $\left(\mathrm{AI}_{50}\right)$. 
Antifeedant activity $\%=\left[\begin{array}{l}\frac{\% \text { of treated leaf }}{\text { eaten }} \\ \begin{array}{l}\% \text { of untreated } \\ \text { leaf eaten }\end{array}\end{array}\right] \times 100$

\section{Haemolymph preparation:}

The haemolymph samples from $4^{\text {th }}$ instars larvae were taken after $72 \mathrm{hrs}$ of treatment with apricot kernel extract and its main components. To calculate the differential haemocytes count (DHC), 100 cells were identified to their typical haemocytes type after staining a smear of haemolymph with Wright's stain (Essawy, 1990).

\section{Corpora allata activity:}

Corpora allata (CA) volume was used as an indicator of the juvenile hormone $(\mathrm{JH})$ level (Pflugefelder, 1948). Larvae were dissected after 24, 48 and $72 \mathrm{hrs}$ of treatment. The method of Armstrong and Carr (1964) was used to calculate the CA surface area.

\section{RESULTS AND DISCUSSION}

Fatty acids and other components in Hexane extract of apricot kernel analysis by (GC-MS):

GC-MS analysis of HEAK identified mainly 3 FAs (Table 1). The total FAs were approximately $77.90 \%$ of the crude extract. The FA components were named, using official libraries, by PA (7.68\%), OL (63.78\%) and LAME (6.44\%). Occurrence of other unidentified compounds in tested extract may be associated with chemical processes during heating of extraction system under condition of n-hexane used.

The obtained Gas Liquid Chromatography (GLC) analysis data of HEAK's FAs composition came nearly equivalent to other previous analyses that possessed OL (74.59\%), LA (19.57\%), Stearic acid $(0.96 \%)$, PA (4.11\%), Palmitoleic acid (0.59\%) and Arachidonic acid (0.18\%). (Abdel Rahman, 2011)

In this respect, HEAK and some of its main fatty acid components were studied for its toxicity and antifeedant effect against CLW larvae in corresponded to methoxyfenozide (Runner $24 \% \mathrm{SC}^{\circledR}$ ).

\section{A. Toxicity tests:}

Toxic effect studies were conducted on HEAK and its main identified FA components with the concentrations range of $\left(100-10000 \mathrm{mg} \mathrm{L}^{-1}\right)$ and $(1250$
- $10000 \mathrm{mg} \mathrm{L}^{-1}$ ) against $2^{\text {nd }}$ and $4^{\text {th }}$ instar larvae of $S$. littoralis respectively during 72 hours of exposure. Meanwhile, the concentrations range of methoxyfenozide was $\left(0.01-5 \mathrm{mg} \mathrm{L}^{-1}\right)$. The toxic effect of the tested compounds $2^{\text {nd }}$ instar larvae of CLW were demonstrated by $\mathrm{LC}_{50}$ values calculated from probit analysis (Table 2).

The recorded data of $\mathrm{LC}_{50}$ values after 24 hours of exposure against $2^{\text {nd }}$ instar larvae of CLW showed the highest toxic compound was $\mathrm{OL}$ with $\mathrm{LC}_{50}$ value (3799.71 $\left.\mathrm{mg} \mathrm{L}^{-1}\right)$ followed by HEAK $\left(\mathrm{LC}_{50}\right.$ value $\left.3995.77 \quad \mathrm{mg} \quad \mathrm{L}^{-1}\right)$ then LAME $\left(\mathrm{LC}_{50}\right.$ value $\left.5406.96 \mathrm{mg} \mathrm{L}^{-1}\right)$. In the mean mean time no apparent toxic effect was observed for methoxyfenozide after 24 hours of exposure. On contrary, after 48 and 72 hours of exposure the data of $\mathrm{LC}_{50}$ values show a broad shift in toxic effect rises of HEAK (3035.615 and $2034.14 \mathrm{mg} \mathrm{L}^{-1}$, respectively) followed by LAME (3260.12 and $2105.734 \mathrm{mg} \mathrm{L}^{-1}$, respectively) versus to a clear drop in OL toxicity (3447.39 and $2157.43 \mathrm{mg} \mathrm{L}^{-1}$, respectively). The initiation of methoxyfenozide toxic effect began after 48 hours at $\mathrm{LC}_{50}$ value $8.77 \mathrm{mg} \mathrm{L}^{-1}$ and then increased after 72 hours at $\mathrm{LC}_{50}$ value 0.152 $\mathrm{mg} \mathrm{L}^{-1}$ to exceed the toxic effects of the crude extract and its tested components.

Likewise, the data illustrated in (Table 3) of $\mathrm{LC}_{50}$ values of the tested treatments against $4^{\text {th }}$ instar larvae of $S$. littoralis showed that HEAK had the highest toxic effects and descending followed by LAME and then lasted by OL all over the indicated interval hours of exposure. The final $\mathrm{LC}_{50}$ values after 72 hours were $3358.654220 .926028 .77 \mathrm{mg} \mathrm{L}^{-1}$ for HEAK, LAME and $\mathrm{OL}$, respectively. While the toxic effect of methoxyfenozide $\left(\mathrm{LC}_{50}\right.$ value $7.145 \mathrm{mg} \mathrm{L}^{-1}$ ) delayed and not appeared before 72 hours of exposure. On the other hand, there was no evidence for lethal effect for palmitic acid within the concentrations range of (100$10000 \mathrm{mg} \mathrm{L}^{-1}$ ) against the treated instar larvae of $S$. littoralis.

Finally, it was conclusively recognized the prevail of HEAK toxicity comparing to its main fatty acid components against the two instar larvae of $S$. littoralis during 72 hours of exposure. The toxic action in the treated larvae was significantly occurred in $2^{\text {nd }}$ more than $4^{\text {th }}$ instar larvae.

\section{Table 1. Identified fatty acids profile of hexane extract of apricot kernel Prunus armeniaca}

\begin{tabular}{clccccc}
\hline No & Identified compounds & Unsaturated bonds & Retention times & V/W & Area\% & Molecular weight \\
\hline 1 & Palmitic acid & $\mathrm{C} 16: 0$ & 31.56 & 0.20 & 7.68 & $\mathrm{C} 16 \mathrm{H} 32 \mathrm{O} 2$ \\
2 & Oleic acid & $\mathrm{C} 18: 1$ & 35.46 & 1.66 & 63.78 & $\mathrm{C} 18 \mathrm{H} 34 \mathrm{O} 2$ \\
3 & Linoleic acid methyl ester & $\mathrm{C} 18: 2$ & 35.82 & 0.17 & 6.44 & $\mathrm{C} 19 \mathrm{H} 34 \mathrm{O} 2$ \\
\hline
\end{tabular}


Table 2. Toxicity of apricot kernels extract, its main fatty acids components and methoxyfenozide against $2^{\text {nd }}$ instar larvae of $S$. littoralis after different periods of exposure

\begin{tabular}{lcccc}
\hline Treatments & $\begin{array}{c}\text { Exposure time } \\
(\mathbf{h r s})\end{array}$ & $\begin{array}{c}\mathbf{L C}_{\mathbf{5 0}} \\
\left(\mathbf{m g ~ L}^{-\mathbf{1}} \mathbf{)}\right.\end{array}$ & Confident limits & Slope \pm S.E. \\
\hline \multirow{2}{*}{ Apricot kernel } & 24 & 3995.77 & $(3174.77-5027.81)$ & $2.57 \pm 0.41$ \\
Extract & 48 & 3035.615 & $(2342.478-385.82)$ & $2.392 \pm 0.37$ \\
& 72 & 2034.14 & $(1492.57-2735.27)$ & $1.90 \pm 0.29$ \\
\hline \multirow{2}{*}{ Linoleic acid } & 24 & 5406.96 & $(4055.09-9269.90)$ & $2.14 \pm 0.57$ \\
methyl ester & 48 & 3260.12 & $(6557.439-4356.11)$ & $2.22 \pm 0.48$ \\
& 72 & 2105.734 & $(1535.51-2863.55)$ & $1.83 \pm 0.29$ \\
\hline \multirow{2}{*}{ Oleic acid } & 24 & 3799.71 & $(2711.73-5105.79)$ & $1.95 \pm 0.43$ \\
& 48 & 3447.39 & $(2596.90-4546.71)$ & $2.02 \pm 0.34$ \\
& 72 & 2157.43 & $(1307.21-3225.69)$ & $1.39 \pm 0.318$ \\
\hline \multirow{2}{*}{ Methoxyfenozide } & 24 & - & - & - \\
& 48 & 8.77 & $(2.90-1300.47)$ & $0.673 \pm 0.237$ \\
\hline
\end{tabular}

a seven different concentrations of tested crude extract and its main components (within the range of $100-10000 \mathrm{mg} \mathrm{L}^{-1}$ ) and methoxyfenozide (within the range of $0.01-5 \mathrm{mg} \mathrm{L}^{-1}$ ), $\mathrm{N}=120$ for each treatment.

(-) no toxic effects occurred after $24 \mathrm{hrs}$ exposure.

Table 3. Toxicity of apricot kernels extract, its main fatty acids components and methoxyfenozide against $4^{\text {th }}$ instar larvae of $S$. littoralis after different periods of exposure

\begin{tabular}{lcccc}
\hline Treatments $^{\mathbf{a}}$ & $\begin{array}{c}\text { Exposure time } \\
(\mathbf{h r s})\end{array}$ & $\begin{array}{c}\mathbf{L C}_{\mathbf{5 0}} \\
\left(\mathbf{m g ~ L}^{-\mathbf{1}} \mathbf{)}\right.\end{array}$ & $\begin{array}{c}\text { Confident limits } \\
\left(\mathbf{m g ~ L}_{\mathbf{1}} \mathbf{)}\right.\end{array}$ & Slope \pm S.E. \\
\hline Apricot kernel & 24 & 4355.44 & $(3650.418-5272.66)$ & $3.189 \pm 0.49$ \\
Extract & 48 & 3875.874 & $(3213.88-4850.28)$ & $3.11 \pm 0.57$ \\
& 72 & 3358.65 & $(2759.00-4134.31)$ & $3.03 \pm 0.55$ \\
\hline \multirow{2}{*}{ Linoleic acid } & 24 & 5480.93 & $(4647.39-6663.26)$ & $3.63 \pm 0.62$ \\
methyl ester & 48 & 4887.22 & $(4192.372-5756.71)$ & $4.051 \pm 0.65$ \\
& 72 & 4220.92 & $(3400.99-5358.39)$ & $2.49 \pm 0.43$ \\
\hline \multirow{2}{*}{ Oleic acid } & 24 & 9422.25 & $(6897.90-25542.23)$ & $2.193 \pm 0.70$ \\
& 48 & 7736.38 & $(5651.52-14490.32)$ & $1.855 \pm 0.43$ \\
& 72 & 6028.77 & $(4445.49-10285.47)$ & $1.70 \pm 0.41$ \\
\hline \multirow{2}{*}{ Methoxyfenozide } & 24 & - & - & - \\
& 48 & - & - & - \\
\hline
\end{tabular}

${ }^{a} \overline{\text { seven different concentrations of tested crude extract and its main components (within the range of } 1250-10000 \mathrm{mg} \mathrm{L}^{-1} \text { ) and }}$ methoxyfenozide (within the range of $0.05-15 \mathrm{mg} \mathrm{L}^{-1}$ ), $\mathrm{N}=120$ for each treatment.

(-) no toxic effects occurred after 24 and $48 \mathrm{hrs}$ exposure.

The data of toxic action of hexane HEAK and some of its main FA components against $2^{\text {nd }}$ and $4^{\text {th }}$ instar larvae of CLW were agreed with the insecticidal activity of some active agents naturally occurred in essential oil from ripe fruits of Melia azedarach and some free individual FAs like LA against $S$. littoralis larvae. (Farag et al. 2011; Yousef, et al., 2013)

However, there were no a definite justifications for the high significant toxicity of HEAK comparing individually by its main FAs OL and PA and their esters compound of LAME, this phenomenon might be attributed to the naturally occurrence of these active agents and other components in the crude extract bulk, may give an indication of some of their synergistic action. This thought meets the report of (Hummelbrunner and Isman, 2001) concerning synergistic effects of complex mixtures (crude extract) of phytochemicals. In addition, apricot kernels contain the toxic cyanogenic glycoside amygdalin depending on their variety (Gomez et al., 1998). Amygdalin can be hydrolyzed by $\beta$-glucoronidase in the human intestine to form glucose, benzaldehyde and released cyanide in the form of hydrocyanic acid (Shragg et al., 1982).

However, PA (C16:0) concentrations have no toxic effects against the treated larvae of CLW, unsaturated FAs of LAME (C18:2) and OL (C18:1) showed relative significant effects. This finding was discussed by several authors such as (Wallace et al., 2006; Margarida 
et al., 2010). Detection of double bond numbers could not explain why 18:3 FAs were more toxic to growth than 18:2 FAs, and especially why 18:1was not toxic for ruminal bacterium Butyrivibrio fibrisolvens. The free carboxyl group disrupted the cell integrity and consequently help growth inhibition to take place. This might give a prospect that the form of free carboxylic FA has more toxicity as originated in LA than their methyl esters form of LAME as study case in this research.

Toxicity effect of the crude extract was rivaled by a common IGR insecticide (Runner 24\% $\mathrm{SC}^{(\mathbb{B}}$; Methoxyfenozide) meet a previous study carried out on lepidopteron species treated with lethal concentrations of ecdysone agonists, the larvae died in a double cuticle without successful ecdysis, meanwhile at lower or sublethal concentrations many survived larvae underwent abnormal and lethal pupation. (Sa'enz de Cabezo'n et al., 2005)

\section{B. Antifeedant effect:}

Comparative studies for all treatments according to concentration-antifeedant responds were illustrated by probit line analysis to find out concentrations that fulfilled with $50 \%$ antifeedant activity $\left(\mathrm{AI}_{50}\right) . \mathrm{AI}_{50}$ values of all tested treatments on second instar larvae of $S$. littoralis after different times of exposure were shown in (Table 4). $\mathrm{AI}_{50}$ values of HEAK were 1475.47 and $2111.787 \mathrm{mg} \mathrm{L}^{-1}$ after 24 and 72 hours, respectively while after 48 hours its antifeedant effect was below $50 \%$ at its highest concentration. Methoxyfenozide had a high significant antifeedant activity as the $\mathrm{AI}_{50}$ values were $0.938,3.11$ and $1.30 \mathrm{mg} \mathrm{L}^{-1}$ after 24,48 and 72 hours, respectively. Besides, the highest concentrations of LAME and OL had an antifeedant activity values lower than $25 \%$. The presented data in (Table 5) showed $\mathrm{AI}_{50}$ values of all treatments on $4^{\text {th }}$ instar larvae after different times of exposure. HEAK had relative antifeedant activity presented in $\mathrm{AI}_{50}$ values of 3814.74 , 3079.88 and $3207.53 \mathrm{mg} \mathrm{L}^{-1}$ after 24, 48 and 72 hours, respectively. $\mathrm{AI}_{50}$ values of methoxyfenozide indicated as $1.43,1.54$ and $1.61 \mathrm{mg} \mathrm{L}^{-1}$ after 24,48 and 72 hours, respectively ravel out its high antifeedant activity. On contrary, the antifeedant activity values were lower than $25 \%$ at the highest concentrations of LAME and OL.

The previous data showed that the antifeedant responds of HEAK was definite prevalence over its FA components but methoxyfenozide was so far owned superior antifeedant responses due to his extreme low $\mathrm{AI}_{50}$ values on the treated larvae.

Antifeedant data against $S$. littoralis larvae emphasized that HEAK clearly revealed significant high effect comparing to its tested FAs of Oleic, PA and LAME. The rate of feeding significantly varied depending on the concentration of the crude extract and its tested active components. This indicates that some active agents in the plants inhibit larval feeding activity or make the food unpalatable or the substances directly act on stimulating the deterrent receptor on chemosensilla of the larva and some antifeedant are thought to block. Also, sugars and amino acids could interfere with the perception of feeding stimulant receptors, while others may cause erratic bursts of electrical impulses in the nervous system resulting in feeding deterrence. (Jeyarajan et al., 1990; Jeyasankar et al., 2012; Jeyasankar et al., 2014)

Table 4. AI $\mathbf{I}_{50}$ values of HAEK, its main components and methoxyfenozide to on $2^{\text {nd }}$ instar larvae of $S$. littoralis

\begin{tabular}{|c|c|c|c|c|c|}
\hline Treatments $^{\mathrm{a}}$ & $\begin{array}{c}\text { Exposure time } \\
\text { (hrs) }\end{array}$ & $\mathbf{A I}_{50}{ }^{\mathrm{b}}\left(\mathrm{mg} \mathrm{L}^{-1}\right)$ & $\begin{array}{l}\text { Confident limits } \\
\left(\mathrm{mg} \mathrm{L}^{-1}\right)\end{array}$ & Slope \pm SD & $\mathbf{X}^{2}$ \\
\hline \multirow{3}{*}{ Apricot kernel extract } & 24 & 1475.47 & $(2108.70-1670.78)$ & $3.02 \pm 0.32$ & 2.15 \\
\hline & 48 & \multicolumn{3}{|c|}{$>50 \%$ antifeedant activity at highest concentration. } & \\
\hline & 72 & 2111.787 & $(1755.58-2738.48)$ & $1.99 \pm 0.24$ & 6.67 \\
\hline \multirow{3}{*}{ Linoleic acid methyl ester } & 24 & & & & \\
\hline & 48 & & & & \\
\hline & 72 & \multicolumn{3}{|c|}{$>25 \%$ antifeedant activity at highest concentration. } & \\
\hline \multirow{2}{*}{ Oleic acid } & 48 & & & & \\
\hline & 72 & & & & \\
\hline \multirow{3}{*}{ Methoxyfenozide } & 24 & 0.938 & $(0.62-1.72)$ & $0.85 \pm 0.12$ & 0.90 \\
\hline & 48 & 3.11 & $(1.39-17.38)$ & $0.60 \pm 0.12$ & 2.12 \\
\hline & 72 & 1.30 & $(0.88-2.28)$ & $1.04 \pm 0.14$ & 3.81 \\
\hline
\end{tabular}

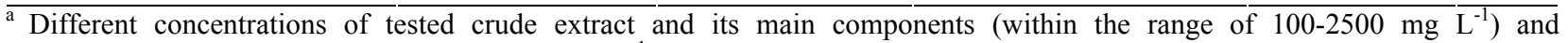
methoxyfenozide (within the range of $0.05-2.5 \mathrm{mg} \mathrm{L}^{-1}$ ), $\mathrm{N}=120$ for each treatment.

${ }^{\mathrm{b}}$ Concentrations of treatments fulfill $50 \%$ antifeedant activity 
Table 5. AI $\mathbf{I}_{50}$ values of HAEK, its main components and methoxyfenozide to on $4^{\text {th }}$ instar larvae of $S$. littoralis

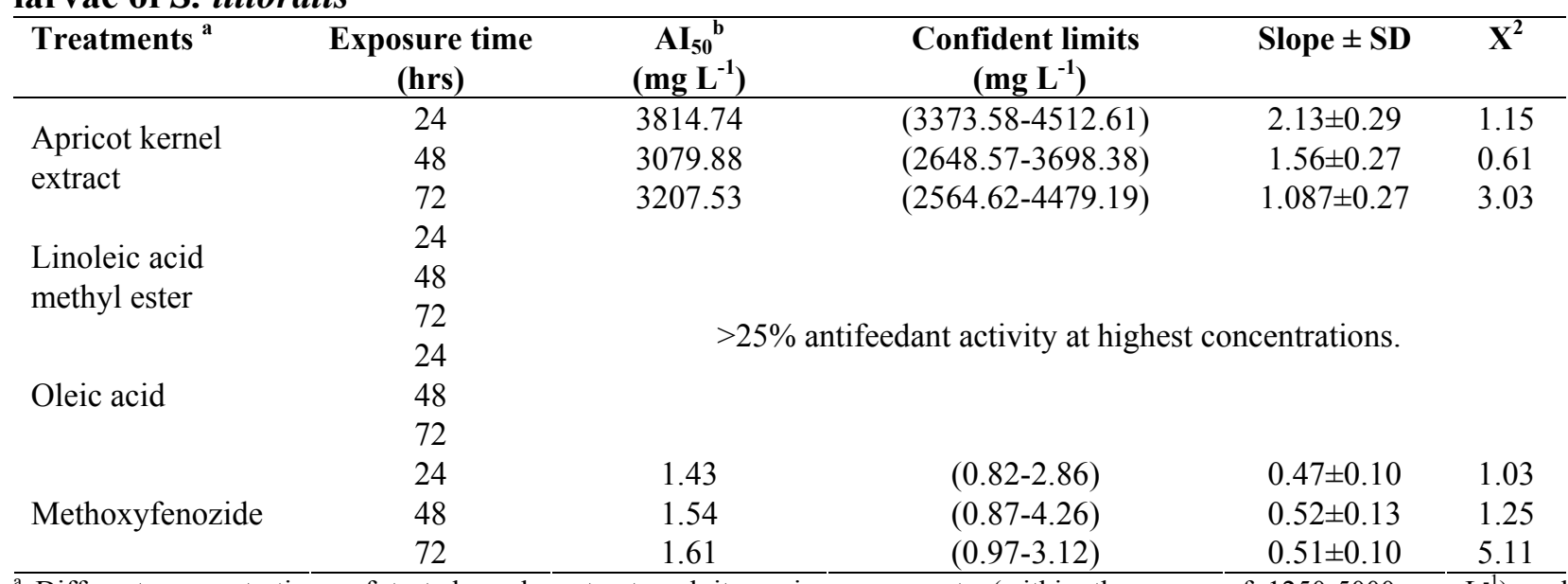

$\overline{{ }^{a} \text { Different concentrations of tested crude extract and its main components (within the range of } 1250-5000 \mathrm{mg}} \overline{\mathrm{L}^{-1} \text { ) and }}$ methoxyfenozide (within the range of $0.1-5 \mathrm{mg} \mathrm{L}^{-1}$ ), $\mathrm{N}=120$ for each treatment.

${ }^{\mathrm{b}}$ Concentrations of treatments fulfill $50 \%$ antifeedant activity

The main FA components represented as OL (C18) and LAME (C19) of the crude extract had a significant very low antifeedant effect only in high concentrations and particularly seemed to be attractive in very low concentrations. This findings were agree with (Ganesan et al., 2006) observations that Longer-chain-length FAs (C12-C18) were attractive at lower levels but repellent at higher levels for Aedes aegypti L. oviposition. While, Straight-chain FAs in the C6-C10 range possessed antifeedant and repellent actions against pine weevils, Hylobius abietis L. and activity dropped with increasing chain length (Mansson et al., 2006).

Disturbance in feeding behavior in CLW larvae treated with methoxyfenozide attributed to its mode of action mimics natural ecdysone, where the reduction of weight could be due to a decrease in feeding activity as a consequence of the activity of the insecticide and the presence of the double cephalic capsule, which interferes with larval feeding. Inhibitions of methoxyfenozide and other IGRs on S. littoralis, and Mythimna unipuncta were detected (Gobbi et al. 2000; Pineda et al. 2007; Federico et al., 2011).

\section{C-Haemocytes count:}

Five haemocyte types that have been identified as Prohaemocytes (Pr), Granulocytes (Gr), Plasmatocytes (Pl), Oenocytoides (Oe) and Spherulocytes $(\mathrm{Sp})$ were monitored after treatment. The effects of apricot kernel extract and its main components after $72 \mathrm{hrs}$ from treatment were evaluated on the haemolymph parameters. All tested compounds clearly affected on the different haemocytes counts of $4^{\text {th }}$ instar larvae of S. littoralis.
(Table 6) shows the fluctuation of the calculated mean number of different haemocytes in the haemolymph of the $4^{\text {th }}$ instar larvae of S. littoralis as a result of apricot kernel extract and its main components after $72 \mathrm{hrs}$ of exposure.

With regard to apricot kernel extract treatment, a reduction in the percentage of the prohaemocyte was observed amounted 9.2 and 8.3 cell, when $\mathrm{LC}_{25}$ and $\mathrm{LC}_{50}$ were used, respectively (Table 6). A significant reduction was observed in the number of granulocyte after treatment with $\mathrm{LC}_{25}$ and $\mathrm{LC}_{50}$ values of apricot kernel extract 26.3 and 23 cell. The same trend was observed in the number of plasmatocytes of the $\mathrm{LC}_{25}$ and $\mathrm{LC}_{50}$ values where the number of plasmatocytes were 24.3 and 23.1 cell, respectively. While the number of Oenocytoides increased being 17.6 and 19.3 cell, respectively. The same trend was observed in spherule cells number being 10.1 and 12.3 cell, respectively.

In the linoleic acid treatment, reduction in the number of the prohaemocyte count was estimated by 8 and 6.5 cell, respectively when $\mathrm{LC}_{25}$ and $\mathrm{LC}_{50}$ were used compared to control, respectively, A significant reduction appeared in the number of granulocyte after treatment with $\mathrm{LC}_{25}$ and $\mathrm{LC}_{50}$ values of linoleic acid. 32.2 and 31.7 cell. The same trend was observed in the number of plasmatocyte in the $\mathrm{LC}_{25}$ and $\mathrm{LC}_{50}$ values were 35 and 33.2 cell, respectively, while the number of Oenocytoides increased being 20.4 and 21.3 cell, respectively. The same trend was observed in spherule cells number being 10.4 and 11.3 cell, respectively. 
Table 6. Effect of HAEK crude extract, its main components on number of haemocytes in the $4^{\text {th }}$ instar larvae of $S$. littoralis after $72 \mathrm{hrs}$ hours of exposure

\begin{tabular}{|c|c|c|c|c|c|c|}
\hline \multirow[t]{2}{*}{ Treatments } & & \multicolumn{4}{|c|}{ Haemocytes number (cells)/100 cell } & \multirow[b]{2}{*}{ Sp } \\
\hline & & Pr & Gr & PI & Oe & \\
\hline \multirow[t]{2}{*}{ Apricot kernel extract } & $\mathrm{Lc}_{25}$ & $9.2 \pm 0.2^{\mathrm{ab}}$ & $26.3 \pm 1.2^{\mathrm{c}}$ & $24.3 \pm 1.6^{\mathrm{c}}$ & $17.6 \pm 1.2^{\mathrm{ab}}$ & $10.1 \pm 1.2^{\mathrm{a}}$ \\
\hline & $\mathrm{Lc}_{50}$ & $8.3 \pm 0.3^{\mathrm{b}}$ & $23 \pm 1.3^{\mathrm{c}}$ & $23.1 \pm 1.2^{\mathrm{c}}$ & $19.3 \pm 1.3^{\mathrm{a}}$ & $12.3 \pm 1.2^{\mathrm{a}}$ \\
\hline \multirow[t]{2}{*}{ Linoleic acid methyl ester } & $\mathrm{Lc}_{25}$ & $8 \pm 0.5^{b}$ & $32.2 \pm 1.2^{\mathrm{ab}}$ & $35 \pm 1.4^{\mathrm{a}}$ & $20.4 \pm 0.6^{\mathrm{a}}$ & $10.4 \pm 0.5^{\mathrm{a}}$ \\
\hline & $\mathrm{Lc}_{50}$ & $6.5 \pm 0.3^{\mathrm{b}}$ & $31.7 \pm 1.3^{\mathrm{b}}$ & $33.2 \pm 1.0^{\mathrm{a}}$ & $21.3 \pm 0.7^{\mathrm{a}}$ & $11.3 \pm 0.7^{\mathrm{a}}$ \\
\hline \multirow[t]{2}{*}{ Oleic acid } & $\mathrm{Lc}_{25}$ & $7.4 \pm 0.3^{b}$ & $35.6 \pm 1.0^{\mathrm{a}}$ & $34.8 \pm 1.2^{\mathrm{a}}$ & $20.2 \pm 0.8^{\mathrm{a}}$ & $10.2 \pm 0.5^{\mathrm{a}}$ \\
\hline & $\mathrm{Lc}_{50}$ & $6.1 \pm 0.2^{\mathrm{b}}$ & $34.3 \pm 0.4^{\mathrm{a}}$ & $32.1 \pm 0.8^{\mathrm{a}}$ & $22.8 \pm 0.8^{\mathrm{a}}$ & $11.8 \pm 0.7^{\mathrm{a}}$ \\
\hline \multirow[t]{2}{*}{ Methoxyfenozide } & $\mathrm{Lc}_{25}$ & $7.3 \pm 0.3^{b}$ & $24.8 \pm 0.3^{\mathrm{a}}$ & $22.2 \pm 0.6^{\mathrm{b}}$ & $16.2 \pm 1.0^{\mathrm{a}}$ & $10.2 \pm 0.5^{\mathrm{a}}$ \\
\hline & $\mathrm{Lc}_{50}$ & $5.3 \pm 0.3^{b}$ & $22.8 \pm 0.3^{b}$ & $20.7 \pm 0.6^{\mathrm{b}}$ & $17 \pm 1.0^{\mathrm{a}}$ & $9.7 \pm 0.4^{\mathrm{a}}$ \\
\hline Control & & $12 \pm 0.6^{\mathrm{a}}$ & $30 \pm 1.2^{\mathrm{b}}$ & $30.1 \pm 1.5^{b}$ & $15 \pm 0.2^{b}$ & $6.5 \pm 0.1^{b}$ \\
\hline
\end{tabular}

- Each value represents the mean $\pm S E$.

- Mean in same column followed by the same letters are not significant.

- Probability level at 0.01 .
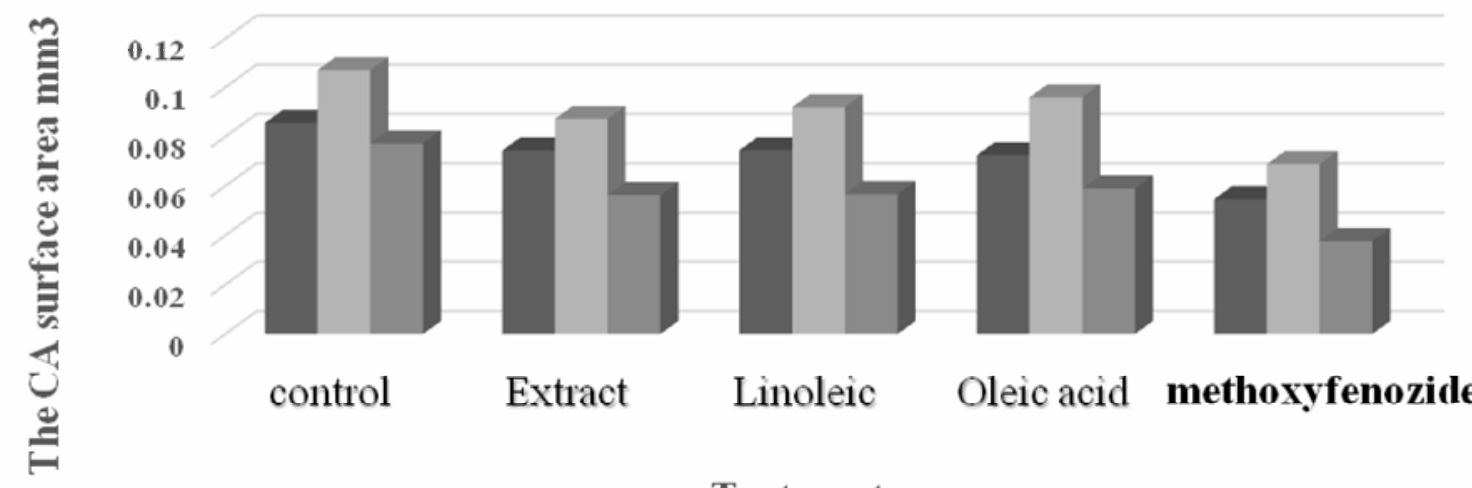

control Extract Linoleic Oleic acid methoxyfenozide

Tratments

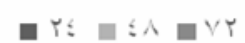
Figure 1. Effect of HAEK crude extract, its main components on the CA surface area in $4^{\text {th }}$
instar larvae of $S$. littoralis

The Oleic acid treatment was characterized its increase in the number of prohaemocyte by 7.4 and 6.1 cell, respectively at $\mathrm{LC}_{25}$ and $\mathrm{LC}_{50}$. A significant increase was observed in the number of granulocytes after treatment with $\mathrm{LC}_{25}$ and $\mathrm{LC}_{50}$ values 35.6 and 34.3 cell, respectively. The same trend was observed in plasmatocyte number being 34.8 and 32.1cell, respectively. Moreover, oenocytoide cells number increased to 20.2 and $22.8 \mathrm{cell}$, respectively .The number of spherule cells increased compared with control 10.2 and 11.8 cell (Table 6).

On contrast, methoxyfenozide treatment significantly decreased the number of prohaemocyte to be 7.3 and 5.3 cell, respectively at $\mathrm{LC}_{25}$ and $\mathrm{LC}_{50}$ values. Also, the number of granulocyte significant decreased being 24.8 and 22.8 cell, respectively .The

same trend was observed in the number of plasmatocyte being 22.2 and 20.7 cell, respectively at $\mathrm{LC}_{25}$ and $\mathrm{LC}_{50}$ values. Furthermore, the number of oenocytoide increased being 16.2 and 17 cell, respectively. The same trend was observed in spherule cells number being 10.2 and 9.7 cell, respectively at $\mathrm{LC}_{25}$ and $\mathrm{LC}_{50}$ values (Table 6). The present result shows that the effect of apricot kernel extract on the different haemocyte counts in $4^{\text {th }}$ instar larvae was similar to the effect of tested insecticide (methoxyfenozide).

These results were similar to those obtained in previous studies (Arnold and Hinks, 1976) when they observed a high mitotic and rapid turnover of spherule cells, possibly as a mechanism of releasing products of their metabolism into the haemolymph. In addition, spherule cells were played an important role in 
recreation of some haemolymph proteins (Akai and Sato, 1973). Also, agreed to the results of ( $\mathrm{Gad}$ and Abdel-Megeed 2006), they observed that spinosad and proclaim decreased the total and differential haemocyte counts also effect and damage on the larval DNA in the Spodoptera littoralis.

(Zibaee et al. 2011) mentioned that estimation of Aspartate (AST) and Alanine aminotransferases (ALT) activity significantly increased in Eurygaster integriceps after exposure to pyriproxyfen. They concluded that possible damages of this insecticide to haemocytes and fat bodies are the reason in elevation of their activity.

\section{D- Corpora allata activity:}

Results reported in Fig., (1) depict that treatment of S. littoralis $4^{\text {th }}$ larval instar with crude extract and its main components caused markedly decreases in the CA surface area after 24, 48, $72 \mathrm{hrs}$ of exposure.

Apricot kernel extract at $\mathrm{LC}_{50}$ markedly decreased the CA surface area, it was $0.0563 \mathrm{~mm}^{3}$ in the treated larvae while control was $0.0776 \mathrm{~mm}^{3}$, the percentage of decrease was $27.44 \%$ after 72 hrs of exposure. Furthermore, linoleic and Oleic acid at $\mathrm{LC}_{50}$ decreased the CA surface area, it were 0.0573 and $0.0586 \mathrm{~mm}^{3}$ in the treated larvae with linoleic and Oleic acid, respectively. The percentage of decrease were 26.2 and $24.4 \%$ after $72 \mathrm{hrs}$ of exposure, respectively. Also, treatment with methoxyfenozide at $\mathrm{LC}_{50}$ caused a sharp decrease in the CA surface area. The CA surface area was $0.0378 \mathrm{~mm}^{3}$ in the treated larvae about $51.3 \% 72$ hrs of exposure.

These results are in agreement with Abou-Taleb et al. (2013), they reported a decrease in the CA activity in $4^{\text {th }}$ larval instar of $\mathrm{S}$. littoralis after treatment with insecticides lufenuron and chlorfluazuron.

\section{CONCLUSION}

It is noticeably showed that toxic action of the HAEK crude extract and its FA constitutes initiated much earlier than methoxyfenozide particularly within the period of 24 hours against $2^{\text {nd }}$ instar and the first 48 hours against $4^{\text {th }}$ instar larvae of $S$. littoralis. We can apparently depend on the toxic and antifeedant responds of HEAK and its main FA constituents in $2^{\text {nd }}$ more than $4^{\text {th }}$ instar larvae.

Prospective studies would be oriented to words the active agents of HEAK and its synergistic effects with other conventional insecticides against CLW and other insect pests.

\author{
Abbreviations: \\ - Cotton leaf worm (CLW) \\ - Hexane extract of apricot kernel (HEAK) \\ - Palmitic acid (PA) \\ - Linoleic acid (LA) \\ - Corpora allata (CA) \\ - Linoleic acid methyl ester (LAME) \\ - Oleic acid (OL) \\ - Insect growth regulator (IGR) \\ - Fatty acid (FA)
}

\section{REFERENCES}

Abbott, W. S. 1925. A method of computing the effectiveness of an insecticide. J. Econ. Entomol. 18: 265-267.

Abdel-Rahman, M. K. 2011. Can apricot kernels fatty acids delay the atrophied hepatocytes from progression to fibrosis in dimethyl nitrosamine (DMN)-induced liver injury in rats? Lipids in Health and Disease. 10: 114.

Abou-Taleb, H. K., H. M. Zahran and A. A. Gad 2015. Biochemical and physiological effects of lufenuron and chlorfluazuron on Spodoptera littoralis (Boisd.) (Lepidoptera: Noctuidae). J. Econ. Entomol. 12(2): 77-86.

Adel, M. M. and F. Sehnal 2000. Azadirachtin potentiates the action of ecdysteroid agonist RH-2485 in Spodoptera littoralis. J. Insect Physiol. 46: 267-274.

Akai, H. S. and S. Sato 1973. Ultrastructure of the larval haemocytes of the silkworm Bombyx mori L. (Lepidoptera: Bombycidae). Int. J. Insect. Morphol. Embryol. 2: 207-231.

Amish, P. V., L. V. Jaswant and N. Subrahmanyam 2010. A review on FAME production processes fuel. 89 (1): 1-9.

Armstrong, W. D. and C. W. Carr 1964. Physiological chemistry laboratory directions (3rd ED).Burges publishing Co., Minneapolis, Minnesota

Arnold, J. W. and C. F. Hinks 1976. Haemopoiesis in Lepidoptera. The multiplication of circulating haemocytes. Can. J. Zoo. 54: 1003-1012.

Biddinger, D., L. Hull, H. Huang, B. McPheron and M. Layer. 2006. Sub lethal effects of chronic exposure to tebufenozide on the development, survival, and reproduction of the tufted apple bud moth (Lepidoptera: Tortricidae). J. Econ. Entomol. 99: 834-842.

Ditrich, V. 1962. "A comparative study of toxicological test methods on a population of the two spotted spider mite (Tetranychus urticae)". J. Econ. Entomol. 55: 644-648.

El-Defrawi, M. E., A. Toppozada, N. Mansour and M. Zaid. 1964. Toxicological studies on Egyptian cotton leaf worm Prodenia litura (F.). I: Susceptibility of different larval instars to insecticides. J. Econ. Entomol. 57: 591 - 593.

EPPO, 1997. Spodoptera littoralis and Spodoptera litura. In: Smith IM, McNamara DG, Scott PR, Holderness M (eds). Quarantine pests for Europe. $2^{\text {nd }}$ edition. Wallingford, UK: CAB International. 518-525.

Essawy, M. M. 1990. Changes in different haemocytes counts of the last larval instar of Spodoptera littoralis (Boisd.) during wound healing. Alex. Sci. Exch. 11(4): 151-176. 
Farag, M., M. H. Ahmed, H. Yousef and A. A. AbdelRahman. 2011. Repellent and insecticidal activities of Melia azedarach L. against cotton leaf worm Spodoptera littoralis (Boisd.). Z. Naturforsch. 66: 129-135.

Federico, R., N. F. Marilina, I. S. Marcela and E. R. Alicia 2011. Lethal and sublethal effects of cypermethrin and methoxyfenozide on the larvae of Rachiplusia $n u$ (Guenee) (Lepidoptera: Noctuidae). Invertebrate Reproduction \& Development. 1-9: I First.

Finney, D. J. 1971. Probit analysis. $3{ }^{\text {rd }}$ Edn. Cambridge University Press, Cambridge. XV, 333S. 41 Rechenbeispiele, 20 Diagr., 8 Tab., 231 Lit., L 5.80.

Gad, A. A. and A. Abdel-Megeed 2006. Effects of spinosad and emamectin benzoate on the blood picture and DNA structure of the cotton leaf worm Spodoptera littoralis (Boisd.) (Lepidoptera: Noctuidae) .The Egyption. Sci. Magazine. 4: 76-80.

Ganesan, K., M. J. Mendki, M. V. Suryanarayana, S. Prakash and R. C. Malhotra 2006. Studies of Aedes aegypti (Diptera: Culicidae) ovipositional responses to newly identified semiochemicals from conspecific eggs. Aust. J. Entomol. 45:75-80.

Georgiou, G. P. 1987. Insecticides and Pest Resistance: The Consequences of Abuse, Faculty Research Lecture, Academic Senate, University of California, Riverside, Calif, USA.

Gobbi, A., F. Budia, M. I. Schneider, P. Del Estal, S. Pineda and E. Vin uela 2000. Accio' n del tebufenocida sobre Spodoptera littoralis (Boisduval), Mythimna unipuncta (Haworth) Spodoptera exigua (Hu“ bner). Bolet1'n de Sanidad Vegetal-Plagas. 26: 119-127.

Gomez, E., L. Burgos, C. Soriano and J. Marrin 1998. Amygdalin content in the seeds of several apricot cultivars. J. Sci. Food Agric. 77: 184-186.

Gupta, A., P. C. Sharma, B. Tilakratne and A. K. Verma. 2012. Studies on physic-chemical characteristics and fatty acid composition of wild apricot (Prunus armeniaca Linn.) kernel oil. Indian J. of natural products and resources. 3(3): 366-370.

Heidi, A. A., A. M. Kordy, A. E. Khaled, N. A. Hassan and N. R. Abdelsalam 2015. Efficiency of using some new insecticides against cotton leaf worm (Spodoptera littoralis) based on biochemical and molecular marker. Alex. Sc. Exch. J. 36(4): 303-313.

Hummelbrunner, L. A. and M. B. Isman 2001. Acute, Sub lethal, Antifeedant and Synergistic effects of monoterpenoid essential oil compounds on the tobacco cutworm Spodoptera litura (Lepidoptera: Noctuidae). Journal of Agricultural and food chemistry. 49: 715-720.

Jeyarajan, S., P. C. Babu, G. Srimannarayana and Y. Geethanjali 1990. Antifeedant and morphogenetic effects of azadirachtin rich fractions on Spodoptera litura F. Botanical Pesticides in Integrated Pest Management. 13: 376-380.
Jeyasankar, A., P. Selvaraj and E. Kuppusamy 2014. Antifeedant and insecticidal activities of selected plant extracts against Epilating beetle Henosepilachna vigintioctopunctata (Coleoptera: Coccinellidae). Advances in Entomology. 2 (1): 14-19.

Jeyasankar, A., S. Premalatha and K. Elumalai. 2012. Biological activities of Solanum pseudocapsicum (Solanaceae) against cotton bollworm, Helicoverpa armigera Hübner and armyworm, Spodoptera litura Fabricius (Lepidoptera: Noctuidae). Asian Pacific J. of Biomedicine. 2: 981-986.

Kannathansan, K., A. Senthilkumar, V. Venkatesalu and M. Chandrasekaram. 2008. Larvicidal activity of fatty acid methyl esters of Vitex species against Culex quinquefasciatus. Parasitol. Res. 103(4): 999-1001.

Koshiya, D. J. and A. B. Ghelani. 1990. Antifeedant activity of different plant derivatives against Spodoptera litura (Fab) on groundnut. Proceedings of the Symposium on Botanical Pesticides in Integrated Pest Management. 270275.

Mansson, P. E., F. Schlyter, C. Erikkson and K. Sjodin 2006. Noanoic acid, other alkanoic acids, and related compounds as antifeedant in Hylobius abietis pine weevils. Entomol. Exp. Appl. 121: 191-201.

Margarida, R. G., C. C. Maia, S. B. Charles, J. R. Anthony, M. Nest, R. L. Tony, A. G. Ian and J. W. Robert 2010. Toxicity of unsaturated fatty acids to the iohydrogenating ruminal bacterium, Butyrivibrio fibrisolvens. BMC Microbiology. 10: 52-56.

Nas, M. N. 2004. "In vitro studies on some natural beverages as botanical pesticides against Erwinia amylovora and Curobacterium flaccumfaciensis subsp. Poinsettia". Turkish J. of Agriculture and Forestry. 28(1): 57-61.

Pflugefelder, O. (1948). Volumetrissche untersuchugen van den corpora allata der Honigbiene Apis mellifera Biol. Zbl. 66: 211235.

Pineda, S., M. I. Schneider, G. Smagghe, A. M. Martinez, P. Del Estal, E. Vin uela, J. Valle and F. Budia 2007. Lethal and sublethal effects of methoxyfenozide and spinosad on Spodoptera littoralis (Lepidoptera: Noctuidae). J. of Econ. Entomol. 100: 773-780.

Rahuman A. A., P. Venkatesan, G. Gopalakrishnan. 2008. Mosquito larvicidal activity of oleic and linoleic acids isolated from Citrullus coloncynthis (Linn.). Parasitol. Res. 103(6): 1383-1390.

Ramos-López, M. A., M. M. González-Chávez, N. C. Cárdenas-Ortega, M. A. Zavala-Sánchez and G. S. Pérez. 2012. Activity of the main fatty acid components of the hexane leaf extract of Ricinus communis against Spodoptera frugiperda. African J. of Biotechnology. 11(18): 4274-4278.

Sa'enz de Cabezo' n, M., V. F. Zalom and I. Pe'rez-Moreno. 2005. Effects of methoxyfenozide on Lobesia botrana (Den y Schiff) (Lepidoptera: Tortricidae) egg, larval and adult stages. Pest Manag. Sci. 11: 1133-1137. 
Saleh, M. A., M. M. El-Bolok, K. A. Abdel Salam and N. A. Ibrahim 1986. Plant extracts affecting insect feeding growth and metamorphosis. Bull. Fac. Agric. Cairo. Uni. 37(1): 526-539.

Shragg, T. A., T. E. Albertson and C. J. Fisher. 1982. Cyanide poisoning after bitter almond ingestion. West J. Med. 136: 65-69.

Smagghe G, Pineda S, Carton B, Del Estal P, Budia F, Vin uela E. 2003. Toxicity and kinetics of methoxyfenozide in greenhouse-selected Spodoptera exigua (Lepidoptera: Noctuidae). Pest Manag. Sci. 59, 1203-1209.
Wallace, R. J., L. C. Chaudhary, N. McKain, N. R. McEwan, A. J. Richardson, P. E. Vercoe, N. D. Walker and D. Paillard 2006. Clostridium proteoclasticum: a ruminal bacterium that forms stearic acid from linoleic acid. FEMS Microbiol Lett. 265: 195-201.

Youssef, H., F. Saheir, Y. El-Lakwah and A. El Sayed 2013. Insecticidal activity of linoleic acid against Spodoptera Littoralis (Boisd.). Egypt. J. Agric. Res. 91 (2):573-580.

Zibaee, A., I. Zibaee and J. J. Sendi (2011). A juvenile hormone analog, pyriproxifen, affects some biochemical components in the haemolymph and fat bodies of Eurygaster integriceps Puton (Hemiptera: Scutelleridae). Pestic. Biochem. Physiol. 100: 289-298.

\section{الملخص العري \\ درلسة اللسمية والتلثير المانع عن الثغية لمستخاص نبلت المشش ومكوناته الفهالة ضد دوة ورق

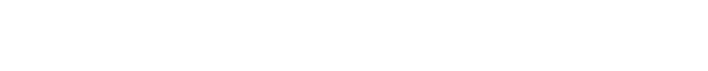

والز محمود خميس،سحر الميد الهسوق، عبير عبد المجيد جاد

المعلملات. وقد تبين من نتائج تأثيرات اللمية والمانع اللتغنية سياة مستخلص نواة المشمش مقارنة بمكوناتهه من

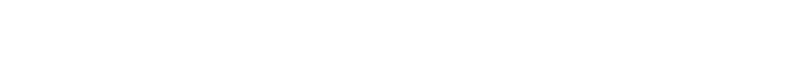

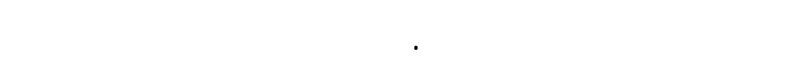

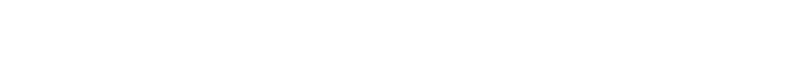

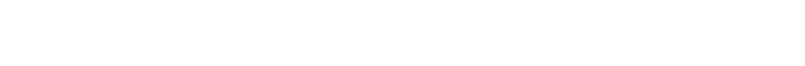
فينوزيد مازل يمتلك الفوق فل أستجابة اليرقلت المعاملة

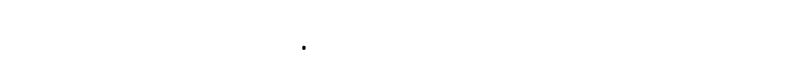

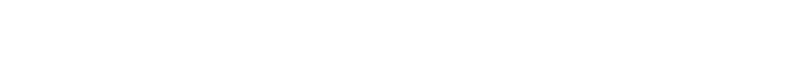

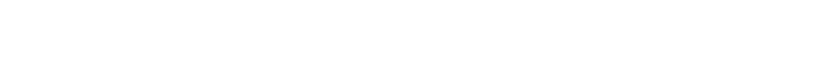

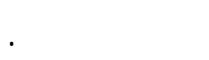

مت درلسة تأثير السمية وللسلوك المانع عن التغذية لمستخلص الهكسان لنوة المشه ومكوناته من الاحماض

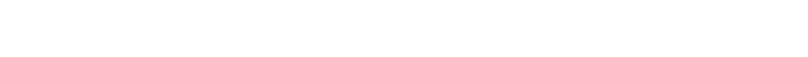

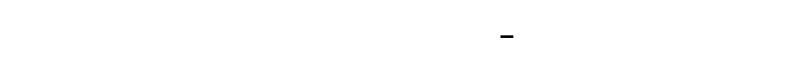
الأحلمض الدهنية(البالمتيك والأولييك) ومشنق الأحماض

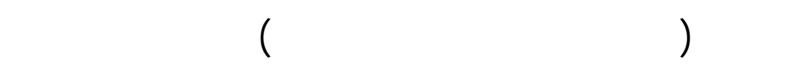
الثاف والرلمع لدوة ورق التطن تحت الظارروف المعملية.

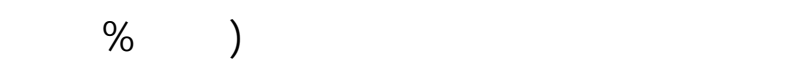
معاق) كمبيد مرجعى المستخلص نوة المشهش ومكوناينه

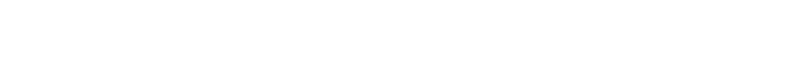
التركيزات النصف قاتلة والتركيزات المسببة للأمتناع بنسبة

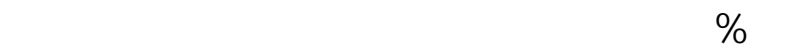

